\title{
IDENTIFIKASI RESIDU PESTISIDA CHLORPYRIFOS DALAM SAYURAN SAWI HIJAU (BRASSICA RAPA VAR. PARACHINENSIS L.) DI PASAR TERONG KOTA MAKASSAR TAHUN 2016 Inayah ${ }^{1}$, Nita Nirmala ${ }^{2}$ \\ ${ }^{1,2}$ Jurusan Kesehatan Lingkungan Poltekkes Kemenkes Makassar \\ $\left.{ }^{*}\right)$ nitanirmala.y@gmail.com
}

\begin{abstract}
Pesticide residues can enter the body through food consumed each day like a vegetable. One of the plants that are often sprayed pesticides are vegetable crops, especially mustard greens (Brassica few var. Parachinensis L.). This happens because of the shape and structure of the mustard plant that allows the worm to nestle in between the leaves. This type of research is an observational study that using checklists or measurement of chlorpyrifos pesticide residues in vegetables green cabbage (Brassica few var. Parachinensis L.). Results of laboratory tests by using gas chromatography showed that the levels of pesticide residues in samples of green cabbage sold at market Eggplant Makassar City with the active ingredient chlorpyrifos before the washing process is equal to $0.276 \mathrm{mg} / \mathrm{kg}$ while the levels of pesticide residues after the washing process is $0 \mathrm{mg} / \mathrm{kg}$.

Based on the standard requirements of ISO 7313 Year 2008 regarding maximum residue limits of pesticides on crops to vegetables green cabbage is $1 \mathrm{mg} / \mathrm{kg}$, then the levels of pesticide residues found in samples of mustard greens before and after the washing process is still below MRL (Maximum residue limits) so meet the health requirements.Decreased levels of chlorpyrifos pesticide residues in vegetables occurs because the process of washing with running water causing the insecticide chlorpyrifos residues found on the surface of the vegetables will be soluble in water. The residue left on the surface of the plant at the time of spraying may be lost due to washing or rinsing.
\end{abstract}

Keywords: Green Mustard (Brassica few var. Parachinensis L.) and Pesticide Residue Levels.

\section{ABSTRAK}

Residu pestisida dapat masuk ke dalam tubuh melalui makanan yang dikonsumsi setiap hari seperti sayuran. Salah satu tanaman yang sering disemprotkan pestisida adalah tanaman sayuran khususnya tanaman sawi hijau (Brassica rapa var. parachinensis L.). Hal ini terjadi karena bentuk dan struktur tanaman sawi yang memungkinkan ulat untuk bersarang di selasela daunnya. Jenis penelitian ini adalah penelitian observasional yakni menggunakan daftar pemeriksaan atau pengukuran terhadap residu pestisida Chlorpyrifos dalam sayuran sawi hijau (Brassica rapa var. parachinensis L.).Hasil pemeriksaan laboratorium dengan menggunakan metode kromatografi gas menunjukkan bahwa kadar residu pestisida pada sampel sawi hijau yang dijual di pasar Terong Kota Makassar dengan bahan aktif chlorpyrifos sebelum proses pencucian adalah sebesar $0,276 \mathrm{mg} / \mathrm{kg}$ sedangkan kadar residu pestisida sesudah proses pencucian adalah $0 \mathrm{mg} / \mathrm{kg}$.Berdasarkan standar persyaratan SNI 7313 Tahun 2008 tentang batas maksimum residu pestisida pada hasil pertanian untuk sayuran sawi hijau yaitu $1 \mathrm{mg} / \mathrm{kg}$, maka kadar residupestisida yang terdapat pada sampel sawi hijau sebelum dan sesudah proses pencucian masih di bawah BMR (Batas Maksimum Residu) sehingga memenuhi syarat kesehatan.Penurunan kadar residu pestisida chlorpyrifos pada sayuran terjadi karena proses pencucian dengan air mengalir menyebabkan residu insektisida chlorpyrifos yang terdapat pada permukaan sayuran akan larut dalam air. Residu yang tertinggal pada permukaan tanaman pada saat disemprot dapat hilang karena pencucian atau pembilasan.

Kata kunci: Sawi Hijau (Brassica rapa var. parachinensis L.) dan Kadar Residu Pestisida.

\section{PENDAHULUAN}

Pangan merupakan kebutuhan yang esensial bagi manusia. Tanpa pangan orang tak dapat hidup. Pangan diperlukan untuk menyusun tubuh, sebagai sumber energi dan zat tertentu untuk mengatur proses metabolisme, tetapi berbeda dengan makhluk hidup yang lain, yang membutuhkan pangan untuk kelangsungan hidup hayati, bagi manusia pangan juga mempunyai nilai untuk kehidupan manusiawi. Pangan telah menjadi unsur kebudayaan. Tidak hanya nilai gizinya saja yang penting, melainkan pangan harus pula disajikan dalam rasa, warna dan bentuk yang sesuai (Ronny, 2009).

Bahan pangan yakni berupa sayuran mengandung vitamin dan mineral yang dibutuhkan tubuh manusia, meskipun dalam jumlah relatif sedikit. Vitamin dan mineral berfungsi sebagai pengatur faali tubuh yang harus selalu ada. Disamping 
kedua zat tadi, sayur-sayuran juga kaya serat yang sangat dibutuhkan tubuh, meskipun tidak dapat dicernakan, tetapi dapat membantu peristaltik usus dan pencernaan makanan.

Sayuran merupakan bagian dari pola makan masyarakat Indonesia, yang dapat diolah menjadi berbagai hidangan yang lezat, di samping lauk pauk lain yang merupakan hidangan sumber zat protein hewani atau nabati, sehingga mutu sayuran tersebut perlu diperhatikan (C.Soejoeti, 1998).

Kendala dalam usaha peningkatan mutu dan produksi sayuran adalah serangan organisme pengganggu (OPT) ataupun penyakit pada daun maupun batang tanaman. Pestisida merupakan pilihan utama untuk mengendalikan hama, penyakit ataupun gulma karena dapat membunuh langsung jasad pengganggu. Pada umumnya pestisida yang digunakan untuk pengendalian jasad pengganggu tersebut adalah racun yang berbahaya, tentu saja dapat mengancam kesehatan manusia. Untuk itu penggunaan pestisida yang tidak bijaksana jelas akan menimbulkan efek samping bagi kesehatan manusia, sumber daya hayati dan lingkungan pada umumnya (Subiyakto, 1991).

Pestisida yang disemprotkan pada tanaman tentu akan meninggalkan residu. Residu pestisida terdapat pada semua bagian tanaman seperti batang, daun, buah dan juga akar. Khusus pada buah, residu terdapat pada permukaan kulit maupun daging dari buah tersebut. Walaupun sudah dicuci atau dimasak residu pestisida ini masih terdapat pada bahan makanan. Residu pestisida golongan organofosfat pada berbagai jenis sayuran seperti bawang merah $0,565-1,167$ ppm, kentang 0,125 - 4,333 ppm, cabe merah 0,024 $1,713 \mathrm{ppm}$ (Sumirat, 2003 dalam Zaenab, dkk. 2011).

Residu pestisida dapat masuk ke dalam tubuh melalui makanan yang dikonsumsi setiap hari seperti sayuran. Salah satu tanaman yang sering disemprotkan pestisida adalah tanaman sayuran khususnya tanaman sawi hijau. Hal ini terjadi karena bentuk dan struktur tanaman sawi yang memungkinkan ulat untuk bersarang di sela-sela daunnya.

Sawi hijau merupakan salah satu jenis sayuran yang dimanfaatkan daunnya dimana di dalam daunnya memiliki kandungan vitamin dan gizi yang tinggi yang bisa dimanfaatkan untuk kesehatan tubuh. Sayur sawi hijau biasanya berupa tumisan dengan berbagai sayuran lain. Berbagai jenis olahan makanan yang dijual, biasanya lebih memilih sawi hijau daripada berbagai jenis sayuran lain. Ini karena sawi hijau memilki rasa khas enak yang tetap nikmat meski dicampur dengan berbagai macam makanan olahan. Salah satu pusat jual beli sayuran, khususnya sayuran sawi hijau yakni di Pasar Terong. Pasar Terong merupakan pasar tradisional yang cukup besar di Makassar yang memasok hasil pertanian dari berbagai wilayah di Sulawesi. Selanjutnya dari pasar ini pula hasil-hasil pertanian tersebut disuplai ke pasar-pasar lain serta daerah-daerah lain.

Salah satu jenis pestisida yang digunakan oleh para petani di Kecamatan Pallangga Kabupaten Gowa pada tanaman sawi hijau adalah pestisida dengan merek dagang yaitu Dursban yang merupakan pestisida golongan organofosfat dengan bahan aktif Chlorpyrifos.

Berdasarkan penelitian yang dilakukan oleh Elvinali Herdariani tahun 2013 tentang Identifikasi Residu Pestisida Klorpirifos Dalam Sayuran Kol Mentah Di Pasar Terong Kota Makassar Dan Sayuran Kol Siap Santap Di Kantin Jasper Universitas Hasanuddin Makassar, diperoleh hasil konsentrasi residu pestisida klorpirifos dalam sayuran kol mentah di Pasar Terong dan sayuran kol siap santap di Kantin Jasper Unhas Makassar tidak terdeteksi berdasarkan batas deteksi alat kromatografi gas yaitu $\geq 0,1 \mathrm{mg} / \mathrm{kg}$. Residu pestisida klorpirifos dalam sayuran kol mentah di Pasar Terong Kota Makassar dan sayuran kol siap santap di Kantin Jasper Unhas Makassar berada di bawah BMR pestisida klorpirifos dalam sayuran kol yaitu $1 \mathrm{mg} / \mathrm{kg}$.

Selain itu, berdasarkan penelitian yang dilakukan oleh Bernard L. Ndalewoa tahun 2013 tentang Identifikasi Residu Pestisida Golongan Organofosfat Berbahan Aktif Klorpirifos Dalam Sayur Jenis Sawi Hijau (Brassica Juncea L) Di Pasar Tradisional (Pasar Terong) Dan Pasar Modern (Pasar Swalayan MTos) Makassar 2013 diperoleh hasil pemeriksaan residu pestisida berbahan aktif klorpirifos pada sampel sawi hijau (Brassica juncea L.) yang diambil dari Pasar Swalayan MTos 
membuktikan bahwa sayuran sawi hijau yang dijual di tempat tersebut bersih dan tidak ada sisa-sisa pestisida berbahan aktif klorpirifos yang menempel, begitu pula dengan sampel sawi hijau yang diambil dari Pasar Terong yang setelah diperiksa juga tidak mengandung klorpirifos. Hasil ini dibuktikan dengan pemeriksaan laboratorium menggunakan metode kromatografi gas pada kedua sampel sawi hijau dan hasil baca alat adalah $0 \mathrm{mg} / \mathrm{kg}$.

$$
\text { Selain }
$$
petani yang mengaplikasikan pestisida, keracunan pestisida dapat pula dialami oleh masyarakat yang mengonsumsi hasil pertanian termasuk sayuran melalui residu pestisida yang terkandung di dalamnya. Berdasarkan data BPOM (Badan Pengawas Obat Dan Makanan) Indonesia, kasus keracunan Nasional yang terjadi pada tahun 2014 akibat pestisida yakni sebanyak 612 kasus.

Residu pestisida bersifat akumulatif di dalam tubuh manusia, sehingga akan memberikan dampak negatif terhadap kesehatan manusia yang mengonsumsi sayuran yang mengandung residu pestisida secara terus menerus. Meskipun hasil tersebut masih dibawah Batas Maksimum Residu (BMR) SNI tahun 2008 yaitu 1 $\mathrm{mg} / \mathrm{kg}$ dan masih dikategorikan aman, hal ini perlu diwaspadai mengingat bahaya Chlorpyrifos pada manusia, seperti efek terhadap sistem saraf pusat mencakup kebingungan, mengantuk, depresi, susah berkonsentrasi, gagap dalam berbicara, insomnia, mimpi buruk, dan menjadi gila (Elvinali, 2013).

Berdasarkan uraian di atas, maka penulis tertarik untuk melakukan penelitian dengan judul : "Identifikasi Residu Pestisida Chlorpyrifos Dalam Sayuran Sawi Hijau (Brassica rapa var. parachinensis L.) Di Pasar Terong Kota Makassar Tahun 2016".

\section{METODE}

\section{Jenis Penelitian}

Adapun jenis penelitian ini adalah penelitian observasional yakni menggunakan daftar pemeriksaan atau pengukuran terhadap residu pestisida Chlorpyrifos dalam sayuran sawi hijau (Brassica rapa var. parachinensis L.).

\section{Gambaran Umum \\ Lokasi penelitian}

Penelitian ini dilaksanakan di Pasar Terong Kota Makassar dan untuk pemeriksaan residu pestisida Chlorpyrifos dalam sayuran sawi hijau (Brassica rapa var. parachinensis L.) dilaksanakan di Laboratorium Pengujian Pestisida Balai Proteksi Tanaman Pangan Dan Holtikultura Sulawesi Selatan.

\section{Waktu penelitian}

Waktu penelitian dibagi menjadi 2 tahap, yaitu:

1) Tahap persiapan yaitu untuk kepentingan penyusunan proposal yang berlangsung pada Desember 2015.

2) Tahap kedua yaitu pelaksanaan kegiatan penelitian yang berlangsung pada bulan Januari sampai Juni 2016.

\section{Variabel Penelitian}

1. Variabel bebas yaitu proses pencucian sayur sawi hijau.

2. Variabel terikat yaitu residu pestisida Chlorpyrifos.

3. Variabel pengganggu yaitu lama waktu pencucian.

\section{Definisi Operasional}

Sayuran sawi hijau (Brassica rapa var. parachinensis $L$.) adalah sayuran sawi hijau yang dijual di Pasar Terong Kota Makassar.

Residu pestisida Chlorpyrifos adalah sisa endapan pestisida yang terdapat pada sayuran sawi hijau (Brassica rapa var. parachinensis $L$.).

Lama waktu pencucian adalah waktu yang digunakan dalam proses pencucian sayur sawi hijau dengan menggunakan air yang memenuhi syarat kesehatan air bersih yaitu dengan cara pencucian menggunkanan air mengalir kemudian perendaman selama 10 menit dan pencucian kembali dengan air mengalir.

\section{Kriteria Obyektif}

Memenuhi syarat: Apabila

residu tidak melebihi batas maksimum residu pestisida yaitu $1 \mathrm{mg} / \mathrm{kg}$ sesuai standar SNI 7313:2008 tentang batas maksimum residu pestisida pada hasil pertanian.

Tidak memenuhi syarat: Apabila tidak sesuai dengan standar. 


\section{Populasi Dan Sampel Populasi}

Sebagai populasi dalam penelitian ini adalah semua sayuran sawi hijau (Brassica rapa var. parachinensis L.) di Pasar Terong Kota Makassar.

\section{Sampel}

Sampel dalam penelitian ini adalah sayuran sawi hijau dengan menggunakan teknik purposive sampling yakni sebanyak 2 sampel

dengan kriteria sayuran sawi hijau (Brassica rapa var. parachinensis L.) yang lebih banyak diperjualbelikan

\section{HASIL}

Berdasarkan hasil penelitian yang dilakukan di Laboratorium pengujian pestisida BPTPH Sulawesi Selatan pada sayuran sawi hijau di Pasar Terong Kota Makassar adalah sebagai berikut:

1. Kadar Residu pestisida Chlorpyrifos dalam sayuran sawi hijau sebelum dilakukan proses pencucian.

Dari hasil pemeriksaan Laboratorium Pengujian Pestisida BPTPH Sulawesi Selatan, kadar residu pestisida Chlorpyrifos dalam sayuran sawi hijau sebelum dilakukan proses pencucian adalah sebesar $0,276 \mathrm{mg} / \mathrm{kg}$.

2. Kadar Residu pestisida Chlorpyrifos dalam sayuran sawi hijau sesudah dilakukan proses.

Dari hasil pemeriksaan Laboratorium Pengujian Pestisida BPTPH Sulawesi Selatan, kadar residu pestisida Chlorpyrifos dalam sayuran sawi hijau sesudah dilakukan proses pencucian adalah $0 \mathrm{mg} / \mathrm{kg}$.

3. Penurunan Kadar Residu pestisida Chlorpyrifos dalam sayuran sawi hijau. Hasil penurunan kadar residu pestisida Chlorpyrifos dalam sayuran sawi hijau setelah mengalami perlakuan (proses pencucian) adalah kadar residu pestisida sebelum proses pencucian yaitu sebesar $0,276 \mathrm{mg} / \mathrm{kg}$ dan sesudah proses pencucian yaitu $0 \mathrm{mg} / \mathrm{kg}$ sehingga kadar residu pestisida mengalami penurunan sebesar $100 \%$.

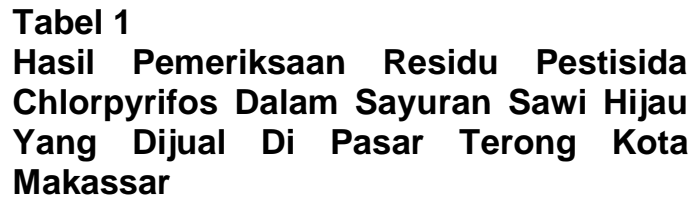

Hasil Pemeriksaan Residu Pestisida Chlorpyrifos Dalam Sayuran Sawi Hijau Yang Dijual Di Pasar Terong Kota Makassar

\begin{tabular}{cccc}
\hline No. & Sawi Hijau & $\begin{array}{c}\text { Hasil } \\
(\mathbf{m g} / \mathbf{k g})\end{array}$ & $\begin{array}{c}\text { Penurunan } \\
(\%)\end{array}$ \\
\hline 1. & $\begin{array}{c}\text { Sebelum } \\
\text { Pencucian }\end{array}$ & 0,276 & \\
2. & $\begin{array}{c}\text { Sesudah } \\
\text { Pencucian }\end{array}$ & 0 & $100 \%$ \\
\hline
\end{tabular}

\section{PEMBAHASAN}

1. Kadar Residu pestisida Chlorpyrifos dalam sayuran sawi hijau sebelum dilakukan proses pencucian.

Dari hasil pemeriksaan kadar residu pestisida di Laboratorium Pengujian Pestisida BPTPH Sulawesi Selatan dengan menggunakan metode Kromatografi Gas menunjukkan bahwa kadar residu pestisida pada sampel sawi hijau di Pasar Terong Kota Makassar dengan bahan aktif Chlorpyrifos sebelum proses pencucian adalah sebesar 0,276 mg/kg.

Berdasarkan standar persyaratan SNI 7313 Tahun 2008 tentang batas maksimum residu pestisida pada hasil pertanian untuk Sayuran sawi yaitu 1 $\mathrm{mg} / \mathrm{kg}$, maka kadar residu pestisida yang terdapat pada sampel sawi hijau yang dijual di Pasar Terong Kota Makassar masih di bawah BMR (Batas Maksimum Residu) sehingga memenuhi syarat kesehatan.

Penelitian yang dilakukan oleh Bernard L. Ndalewoa tahun 2013 tentang Identifikasi Residu Pestisida Golongan Organofosfat Berbahan Aktif Klorpirifos Dalam Sayur Jenis Sawi Hijau (Brassica Juncea L) Di Pasar Tradisional (Pasar Terong) Dan Pasar Modern (Pasar Swalayan M'Tos) Makassar 2013, diperoleh hasil pemeriksaan residu berbahan aktif klorpirifos pada sampel sawi hijau di dua lokasi tersebut bersih dan tidak ada sisasisa pestisida berbahan aktif klorpirifos yang menempel.

Sayuran sawi hijau merupakan salah satu tanaman yang sering disemprotkan pestisida karena bentuk dan struktur tanaman sawi hijau yang memungkinkan ulat untuk bersarang di sela-sela daunnya. 
Hasil uji residu pestisida pada sampel sawi hijau menunjukan bahwa kandungan Chlorpyrifos di dalam sawi tersebut masih dibawah Batas Maksimum Residu (BMR) SNI 7313 tahun 2008 yaitu 1 $\mathrm{mg} / \mathrm{kg}$, namun bukan berarti bahwa sawi tersebut sudah aman dikonsumsi. Hal ini disebabkan karena sebagian besar petani sayur tidak hanya menyemprotkan satu jenis pestisida saja melainkan juga pestisida lain yang bisa mendukung pertumbuhan tanaman tersebut sehingga masih terdapat kemungkinan adanya zatzat pestisida lain dalam sayuran sawi hijau.

Pestisida yang disemprotkan pada tanaman tentu akan meninggalkan residu. Residu pestisida bersifat akumulatif di dalam tubuh manusia, sehingga akan memberikan dampak negatif terhadap kesehatan manusia yang mengonsumsi sayuran yang mengandung residu pestisida secara terus menerus. Kadar residu pestisida yang rendah dalam sayuran, jelas tidak akan menimbulkan gejala keracunan kronis dan akut, tetapi dapat menimbulkan efek subtil (Subtle effect) yaitu efek lanjut jangka panjang yang terjadi pada dosis rendah yang berkali-kali (Dinanti,dkk,2015).

Residu pada tingkat yang aman perlu dikendalikan melalui pengawasan pelaksanaan pengendalian hama penyakit. Sanitasi saat panen dan penanganan pasca panen sangat penting untuk meminimumkan kontaminasi mikroba. Upaya atau tindakan untuk mengurangi pertumbuhan dan perkembangan jamur dan bakteri yang menghasilkan toksin perlu dilakukan sejak pra panen hingga pasca panen.

Pestisida setelah disemprotkan pada tanaman menurut Novizan, 2013 akan segera terkena pengaruh lingkungan. Setelah disemprotkan kemungkinan pertama yang akan terjadi adalah angin akan meniup embun (butiran semprot) hasil penyemprotan pestisida, sehingga menyebabkan perpindahan pestisida ke daerah yang tidak diharapkan. Walaupun butiran semprot pestisida sampai ke daerah sasaran, sebarannya tidak lagi merata. Jika hal ini terjadi pada penyemprotan herbisida, akan terjadi kematian atau kerusakan pada tanaman pokok. Kemungkinan lain yang terjadi pada pestisida setelah disemprotkan adalah :

a. Run off atau aliran permukaan. Sebagian dari butiran semprot yang membasahi daun menetes jatuh ke tanah, mungkin karena penyemprotan yang terlalu lama disatu tempat atau karena butiran semprot yang terlalu besar. Tetesan pestisida yang jatuh dari tajuk tanaman ini berpotensi menyebabkan pencemaran lingkungan.

b. Penguapan, yaitu perubahan bentuk pestisida setelah disemprotkan dari bentuk cair menjadi gas dan hilang di atmosfer.

c. Fotodekomposisi, penguraian pestisida menjadi bentuk yang tidak aktif karena pengaruh cahaya.

d. Penyerapan oleh partikel tanah. Hal ini menyebabkan tertimbunnya sisa pestisida di dalam tanah. Selain itu, penyerapan bahan aktif pestisida oleh tanah akan menurunkan efektivitas pestisida yang memang ditujukan untuk mengendalikan hama yang terdapat di bawah permukaan tanah.

e. Pencucian pestisida oleh hujan dan terbawah ke lapisan tanah bagian bawah dan akhirnya mencemari sumber air tanah dan air sungai.

f. Reaksi kimia, yaitu perubahan molekul pestisida menjadi bentuk yang tidak aktif atau tidak beracun (Novizan, 2013).

g. Perombakan oleh mikroorganisme tanah. Bahan pembentuk pestisida setelah disemprotkan akan menjadi bagian dari tubuh mikroorganisme. Kadar Residu pestisida Chlorpyrifos dalam sayuran sawi hijau sesudah dilakukan proses pencucian.

Dari hasil pemeriksaan kadar residu pestisida di Laboratorium Pengujian Pestisida BPTPH Sulawesi Selatan menunjukkan bahwa kadar residu pestisida pada sampel sawi hijau dengan bahan aktif Chlorpyrifos sesudah proses pencucian adalah $0 \mathrm{mg} / \mathrm{kg}$.

Berdasarkan standar persyaratan SNI 7313 Tahun 2008 tentang batas maksimum residu pestisida pada hasil pertanian untuk Sayuran sawi yaitu $1 \mathrm{mg} / \mathrm{kg}$, maka kadar residu pestisida yang terdapat pada sampel sawi hijau sesudah proses pencucian masih di bawah BMR (Batas Maksimum Residu) sehingga memenuhi syarat kesehatan.

Berdasarkan hasil penelitian yang dilakukan oleh Made Rizki Putri Dinanti, dkk tahun 2015 tentang Pengaruh Perlakuan 
Pencucian Dan Perebusan Terhadap Kadar Residu Insektisida Klorpirifos Dan Karakteristik Kacang Panjang, diperoleh hasil bahwa klorpirifos dipengaruhi oleh lama pencucian dan perebusan. Kadar residu insektisida sebesar $0,0086 \mathrm{mg} / \mathrm{kg}$, akibat perlakuan terjadi penurunan kadar residu insektisida klorpirifos pada kacang panjang. Kadar residu pada kacang panjang yang mengalami perlakuan pencucian selama 10 detik mengalami penurunan yaitu menjadi $0,0046 \mathrm{mg} / \mathrm{kg}$ sedangkan kadar residu pada kacang panjang yang mengalami perlakuan pencucian selama 20 detik mengalami penurunan $0,0043 \mathrm{mg} / \mathrm{kg}$.

Penurunan kadar residu pestisida chlorpyrifos pada sayuran terjadi karena proses pencucian dengan air mengalir menyebabkan residu insektisida chlorpyrifos yang terdapat pada permukaan sayuran akan larut dalam air. Residu yang tertinggal pada permukaan tanaman pada saat disemprot dapat hilang karena pencucian atau pembilasan. Sayuran sawi hijau dalam penelitian ini mengalami proses pencucian dengan cara dibilas dengan air bersih yang mengalir (cuci bagian-bagian sayur dengan detil), kemudian direndam dalam air selama 10 menit, kemudian bilas kembali dengan air bersih yang mengalir. Air bersih yang mengalir bertujuan untuk membersihkan daun dari zat kimia berbahaya dan membersihkan kotoran (tanah) yang masih menempel pada batang maupun akar-akarnya. Proses pencucian dengan cara direndam diharapkan terjadi pelepasan dan penguraian pestisida ke dalam air untuk mendesak keluar lebih banyak pestisida, setelah direndam dibilas lagi dengan air bersih. Air yang digunakan dalam proses pencucian adalah air yang memenuhi syarat kesehatan air bersih.

Residu pestisida terdapat pada semua bagian tanaman seperti batang, daun, buah dan juga akar pada hasil panen khususnya sayuran. Jangka waktu lamanya residu pestisida yang terkandung dalam suatu jenis sayuran tergantung dari jenis bahan kimia dari pestisida tersebut. Hal ini tentu justru dapat berdampak bagi pengonsumsi sayur karena kandungan residu pestisida yang ikut termakan akan memberi dampak negatif bagi kesehatan tubuh manusia itu sendiri (Bambang, 2005). Konsumen cenderung memilih sayuran yang nampak sempurna dari segi fisik. Namun mereka tidak (belum) memperhatikan dari segi kandungan residu pestisida yangterdapat dalam tanaman tersebut. Jika seluruh sayuran yang dikonsumsi membawa residu pestisida sedikit demi sedikit akan terakumulasi dalam tubuh dan pada akhirnya akan menimbulkan berbagai macam jenis penyakit. Adapun ciri-ciri sayuran yang mengandung residu pestisida yaitu, tampak lebih mengkilat, licin, dan menarik, tidak dimakan ulat, akan lebih sulit membusuk setelah dipetik (dipanen).

Selain keracunan langsung, dampak negatif pestisida bisa mempengaruhi kesehatan orang awam yang bukan petani, atau orang yang sama sekali tidak berhubungan dengan pestisida. Kemungkinan ini bisa terjadi akibat sisa racun (residu) pestisida yang ada didalam tanaman atau bagian tanaman yang dikonsumsi manusia sebagai bahan makanan. Konsumen yang mengkonsumsi produk tersebut, tanpa sadar telah kemasukan racun pestisida melalui hidangan makanan yang dikonsumsi setiap hari. Jika residu pestisida terlalu tinggi pada tanaman, maka akan membahayakan manusia yang mengkonsumsi tanaman tersebut. Makin tinggi residu, makin berbahaya bagi konsumen (Bambang, 2005).

Untuk mengurangi residu pestisida pada sayuran, ada beberapa cara yang dapat dilakukan, antara lain:

1. Sayur dicuci dengan air mengalir. Mencuci sayuran dengan air mengalir akan menghilangkan sekitar $25 \%-75 \%$ residu pestisida yang terdapat pada sayuran, tetapi tergantung juga pada jenis pestisidanya.

2. Sayur dicuci dengan cairan anti septik khusus. Adanya lapisan putih atau yang sering disebut lapisan lilin/paraffin yang merupakan lapisan sejenis minyak yang menempel pada sayur yang dapat menyerap partikel pestisida, akan hilang jika dicuci dengan cairan antiseptik khusus dan di cuci hingga bersih.

3. Dikupas kulitnya atau bagian terluar dibuang. Sayuran yang berlapis, hendaknya dibuang lapisan paling luarnya, karena pada bagian terluarlah yang paling banyak terpapar oleh pestisida. Kemudian 
bagian dalamnya juga harus tetap dicuci.

4. Sayur direndam dengan air panas/hangat. Pestisida akan terurai dan lepas pada suhu panas, jadi, merendam sayur dalam suhu panas.

5. Penurunan Kadar Residu pestisida Chlorpyrifos dalam sayuran sawi hijau.

Hasil pemeriksaan Laboratorium menunjukkan bahwa penurunan kadar residu pestisida Chlorpyrifos dalam sayuran sawi hijau setelah mengalami perlakuan (proses pencucian) adalah sebesar $100 \%$. Kadar residu pestisida sebelum proses pencucian adalah sebesar $0,276 \mathrm{mg} / \mathrm{kg}$ dan sesudah proses pencucian adalah $0 \mathrm{mg} / \mathrm{kg}$.

Terdapat perbedaan penurunan kadar residu pestisida pada sayuran sawi hijau yang diberi perlakuan. Adanya perbedaan ini tidak terlepas dari perlakuan pencucian yang diberikan. Penurunan jumlah residu dipengaruhi oleh beberapa faktor, yaitu :

a. Daya Larut. Residu pestisida dapat melarut pada air pencuci. Hal ini berkaitan dengan sifat fisik dan kimia, yaitu kelarutan dalam air dan $\mathrm{pH}$ air pencuci.

b. Hidrolisis. Residu insektisida dapat terhidrolisis tergantung pada jumlah air yang ada, $\mathrm{pH}$, konsentrasi insektisida.

Residu pestisida dapat hilang atau terurai melalui proses dan kadang-kadang berlangsung dengan derajat yang konstan. Residu pestisida dapat terjadi pada tanaman (daun, buah, cabang, akar), tanah, dan air, juga dipengaruhi oleh jenis insektisida yang digunakan, antara lain daya larut dalam air, polaritas, reaktif dan stabilitas kimia.

Menurut Djojosumarto (2008), residu pestisida pada komoditas pertanian dipengaruhi oleh berbagai faktor berikut :

1. Jenis Pestisida.

a. Persistensi pestisida. Pestisida yang persistensi tinggal lebih lama pada tanaman dibandingkan yang tidak persisten.

b. Sistemik/non-sistemik. Pestisida sistemik tinggal lebih lama daripada yang non-sistemik. Sifat-sifat kimia-fisik, degradasi dan metabolit. Pestisida yang mudah didegradasi (dengan kata lain tidak persisten) di lingkungan akan kurang menimbulkan residu dibandingkan pestisida yang lebih persisten. Hasil degradasi pestisida bisa saja menjadi bahan kimia yang berbahaya, meskipun umumnya tidak.

c. Formulasi solvent, carrier, impurity, dsb. Residu pestisida bukan hanya ditentukan oleh bahan aktif nya, tetapi juga oleh bahan-bahan pembantu (adjuvant) dan bahan pembawanya (carrier).

2. Teknik Aplikasi/Penggunaan Pestisida.

a. Jumlah aplikasi per musim (makin banyak jumlah aplikasi, kemungkinan makin banyak residunya).

b. Takaran aplikasi (makin tinggi takaran kemungkinan makin banyak pula residunya).

c. Masa tunggu (holding period, pre harvest interval).

3. Jenis Tanaman

Residu pestisida bisa tinggal lebih lama pada tanaman yang satu dibandingkan tanaman yang lainnya.

4. Iklim dan Cuaca

Suhu udara sangat memengaruhi residu pestisida. $\mathrm{Di}$ daerah beriklim panas degradasi pestisida lebih cepat dibandingkan daerah beriklim sedang. Banyaknya curah hujan juga memengaruhi residu pestisida pada tanaman. Hujan bisa "mencuci" pestisida yang terdapat di permukaan tanaman. Demikian pula matahari juga mempercepat degradasi pestisida.

5. Penanganan Pascapanen

a. Pengupasan dan pencucian pada umumnya akan menurunkan residu.

b. Pemasakan dan pemrosesan lebih lanjut akan lebih menurunkan lagi residu tersebut.

\section{KESIMPULAN}

Berdasarkan hasil penelitian yang dilaksanakan, maka dapat disimpulkan bahwa:

1. Kadar residu pestisida Chlorpyrifos dalam sayuran sawi hijau (Brassica rapa var. parachinensis L.) sebelum dilakukan proses pencucian yaitu sebesar $0,276 \mathrm{mg} / \mathrm{kg}$.

2. Kadar residu pestisida Chlorpyrifos dalam sayuran sawi hijau (Brassica rapa var. parachinensis L.) sesudah dilakukan proses pencucian yaitu $0 \mathrm{mg} / \mathrm{kg}$. 


\section{SARAN}

Adapun yang menjadi saran dalam penelitian ini adalah :

1. Agar petani menggunakan insectisida dengan bahan aktif chlorphyrifos karena chlorphyrifos relatif tidak persisten terhadap lingkungan serta mudah larut dalam air.

2. Kepada masyarakat agar melakukan proses pencucian bahan makanan yang akan dikonsumsi dengan menggunakan air yang mengalir atau perendaman.

3. Untuk penelitian lebih lanjut mengenai akumulasi penurunan residu insektisida yang dilakukan dengan perendaman menggunakan larutan garam yang kemudian dicuci menggunakan air mengalir.

\section{DAFTAR PUSTAKA}

BPOM. 2014. Sentra Informasi Keracunan (SIKer) Nasional. Retrieved (http://ik.pom.go.id/v2015/, diakses 22 Desember 2015).

Dinanti, Made Rizki Putri, dkk., 2015. Pengaruh Perlakuan Pencucian Dan Perebusan Terhadap Kadar Residu Insektisida Klorpirifos Dan Karakteristik Kacang Panjang. , pp.4757. Available at: file:///C:/Users/creative/Downloads/16910-40542-2-PB.pdf, diakses 06 Juni 2016.

Djojosumarto, P., 2008. Pestisida dan Aplikasinya. Jakarta: PT. Argomedia Pustaka.

Farida, I., 2007. Faktor-faktor yang Berhubungan Dengan Perilaku Konsumsi Buah Dan Sayur Pada Remaja Indonesia Tahun 2007. Available at: http://lib.ui.ac.id/, diakses 22 Desember 2015.

Herdariani, E., 2013. Identifikasi Residu Pestisida Klorpirifos Dalam Sayuran Kol Mentah Di Pasar Terong Kota Makassar Dan Sayuran Kol Siap Santap Di Kantin Jasper Universitas Hasanuddin Makassar. Jurnal Elvinali Herdariani. Available at: http://repository.unhas.ac.id/, diakses 22 Desember 2015.

Iskandar, Adang, Dkk. 1985. Pemberantasan Serangga Dan Binatang Pengganggu. Jakarta: Pusat Pendidikan Tenaga Kesehatan Departemen Kesehatan RI.

Marzuki, Aznah, dkk. 2014. Analisis Residu Klorpirifos Pada Sawi Hijau (Brassica Rapa Var.Parachinensis L.) Terhadap Parameter Waktu Retensi Metode Kromatografi Gas. Jurnal IImiah Farmasi, Vol. 3 No. 4 November 2014 ISSN 2302 - 2493. Available at: http://download.portalgaruda.org/, diakses 22 Desember 2015.

Ndalewoa, B.L., 2014. Identifikasi Residu Pestisida Golongan Organofosfat Berbahan Aktif Klorpirifos Dalam Sayur Jenis Sawi Hijau (Brassica Juncea L) Di Pasar Tradisional (Pasar Terong) Dan Pasar Modern (Pasar Swalayan M'Tos) Makassar 2013. , pp.1-89. Available at: http://repository.unhas.ac.id/, diakses 22 Desember 2015.

Novizan. 2002. Petunjuk Pemakaian Pestisida. Jakarta: Agromedia Pustaka.

Republik Indonesia. 2001. Peraturan Menteri Pertanian RI, SK No 434 1/Kpts/TP.270/7/2001, Syarat dan Tata Cara Pendaftaran Pestisida.

Santoso, B.B., 2005. Bab 5 standarisasi mutu produk pasca panen. Available at: http://fp.unram.ac.id/, diakses 3 Januari 2016.

Sudarmo, Subiyakto. 1991. Pestisida. Yogyakarta: Kanisius.

Widya, Nurul. 2012. Pestisida. Retrieved (jujubandung.wordpress.com, diakses 21 Januari 2016). 
Jurnal Sulolipu : Media Komunikasi Sivitas Akademika dan Masyarakat Vol. 17 No I 2017

e-issn : 2622-6960, p-issn : 0854-624X

Wudianto, Rini. 2005. Petunjuk Penggunaan Pestisida. Jakarta: Penebar Swadaya.

Zaenab, dkk. 2011. Analisis Residu Pestisida Ditinjau Dari Kualitas Dan Keamanan Sayuran Di Kelurahan Pattapang Kec. Tinggimoncong Kab.Gowa Tahun 2011. Resbinakes tidak diterbitkan. Makassar: Riset Pembinaan Tenaga Kesehatan. 